\title{
UTILIZATION OF AGRICULTURAL DRAINAGE WATER FOR LETTUCE PRODUCTION IN NFT HYDROPONIC SYSTEM
}

\author{
Abdel-Kader M. Mohammed ${ }^{1 *}$, A.M. Zedan ${ }^{2}$ and M.A. Rizk ${ }^{1}$ \\ 1. Agric. Dept. Soil and Water Res., Nuclear Res. Cent., Atomic Energy Authority, 13759 Abou \\ Zaabl, Egypt
}

2. Agric. Engin. Dept., Fac. Agric., Zagazig Univ., Egypt

\begin{abstract}
Using alternative water resources such as agricultural drainage water is considered very important to produce crops (e.g., lettuce plant) due to fresh irrigation water shortage, especially in arid and semiarid regions like Egypt. Moreover, production of lettuce hydroponically in economical scale is becoming popular in drought prone areas with less water consumption. This study aimed to explore the effects of irrigation with different combinations of Agricultural Drainage Water (ADW) and fresh water on lettuce (Lactuca sativa L.) yield, quality, and water use efficiency (WUE) under hydroponic conditions. Three combinations were applied as: T1, (100\% agricultural drainage water), T2, (50\% agricultural drainage water $+50 \%$ fresh water), T3, (100\% fresh water). Nutrient Film Technique (NFT) hydroponic system was developed with three pipes and nutrient solution added in rates of $12.5 \%, 50 \%$, and $100 \%$ from standard nutrient solution for T1, T2, and T3, respectively. It seems that lettuce plant can be produced in 50 days from planting to harvest the entire system. T2 treatment was effective in increasing the green and dry matter yields, where the green yields accounted for 2.330, 10.587 , and $7.090 \mathrm{~kg} / \mathrm{m}^{2}$ for $\mathrm{T} 1, \mathrm{~T} 2$, and $\mathrm{T} 3$, respectively. The highest lettuce yields as affected by water treatments could be ranked as follow $\mathrm{T} 2>\mathrm{T} 3>\mathrm{T} 1$. This may be attributed to nutritive value of ADW especially at $50 \%$ treatment. Moreover, plants irrigated with T2 have ability to use irrigation water more efficiently than those irrigated with other water treatments. Water Use Efficiency values (WUE) were 8.96, 39.215, and $24.451 \mathrm{~kg} / \mathrm{m}^{3}$ for T1, T2 and T3, respectively. Mineral nutrient contents of $\mathrm{N}, \mathrm{P}, \mathrm{K}$, and $\mathrm{Ca}$ in dry matter were obviously higher in plants irrigated with T3 than other water treatments. This may be due to nutrient solution concentration rates. Heavy metals $(\mathrm{Cd}, \mathrm{Ni}, \mathrm{Cr}$ and $\mathrm{Pb})$ contents in lettuce shoots were higher in plants irrigated with T2 than those irrigated with other water treatments, but their levels did not exceeds the critical levels noted by FAO for edible crops. In conclusion, the NFT hydroponic lettuce could be irrigated safely with agricultural drainage water (ADW) mixed with fresh water in ratio of (50\%: 50\%) (T2) to produce remarkable economical yield with less water requirement. Moreover, use of agricultural drainage water (ADW) in irrigation of lettuce in hydroponic system could be considered as useful alternative source of wastewater without environmental risk of heavy metals accumulation in soil.
\end{abstract}

Key words: Agricultural drainage water, heavy metals, lettuce plant, NFT hydroponic system, water use efficiency.

\section{INTRODUCTION}

Egypt is an arid country, which covers an area of about $1,001,450 \mathrm{~km}^{2}$ of which only $4 \%$ is occupied by its population. The population has tripled during the last 50 years from 19 million in 1947 to about 83.5 million in 2012 and expected to be about 100 million by the year

\footnotetext{
* Corresponding author: Tel. : +201095351203

E-mail address: abdelkader_30@yahoo.com
} 
2025 (Abdel-Lateef et al., 2011). About 99\% of the Egyptian population is concentrated within $5.5 \%$ of the area of the Nile Valley and Delta region. They are extremely dependent on the River Nile for agriculture, drinking water and energy. Where, the actual water resources currently available for use in Egypt are 55.5 $\mathrm{BCM} / \mathrm{yr}$ from river Nile, and $1.3 \mathrm{BCM} / \mathrm{yr}$ effective rainfalls on the northern strip of the Delta, non-renewable groundwater for western desert and Sinai, while water requirements for different sectors are in the order of 79.5 $\mathrm{BCM} / \mathrm{yr}$. The gap between the needs and availability of water is about $20 \mathrm{BCM} / \mathrm{yr}$. This gap is overcome by wastewater recycling.

On the other hand, the agricultural sector is utilizing about $86 \%$ of the available water supplies; however, this amount of water that returns to drains from irrigated lands is relatively high (about 25 to 30\%). Generally, the drainage water from agriculture is collected, by an extensive drainage network. Currently about 5.5 BCM of drainage water are being reused after mixing with fresh water. This amount is expected to increase up to 9.6 BCM by the year 2017. In general, the utilization of agricultural drainage water (ADW) and marginal quality surface water is an emerging necessity to deal with severe water shortage in arid and semi-arid land. Upgrading of ADW may enable appropriate schemes for controlled application depending on treated ADW or via mixing with other sources of surface water. Its reuse in Egypt for agriculture could bridge the gap between the expected (74 milliard $\mathrm{m}^{3}$ ) and required (85 milliard $\mathrm{m}^{3}$ ) water demand. In addition, agriculture drainage water can be considered as a nutrient-rich resource that can be used for food production and thus help alleviate food shortages with minimum use of chemical fertilizers. However, whatever its application, and whatever the type and level of treatment technologies, they must meet the recommended microbiological and chemical quality guidelines. These presume low cost and minimal operational and maintenance requirements.

Hydroponics is a method of growing plants in a soilless environment. The nutrient source is provided directly to the plant roots in solution. Recent studies have indicated that nutrients from treated wastewater could be purified by using some plant species in a hydroponic system
(Vaillant et al., 2004; Yang et al., 2008; Snow and Ghaly, 2008; Rababah and Ashbolt, 2000; Rababah and Al-Shuha, 2009). Moreover, hydroponics (soilless) culture could lead to solve the global issues such as the shortage of water, environmental pollution, and instability of ecological system in various ways. Constituting high values for agricultural crops by using low water inputs and high fertilizer efficiencies is one of the methods used in addressing the environmental and resource problems (Sezen et al., 2010). Hydroponic culture could be arranged with optimum environmental medium for crop growth in order to gain maximum yield and high quality products. However, there are few studies on the nutrient availability in agriculture drainage water for optimum plant growth, pathogen contamination in edible parts of the plant and nutritional quality of vegetables grown in agriculture drainage water using the hydroponics system. One of the most important aspects of fresh food is its nutritional quality; however, it is not clear whether agriculture drainage water is able to provide necessary nutrients to food crops as well as adequate nutritional quality of the product. The current study aimed to investigate lettuce yield and quality, water use efficiency, and heavy metal contents using agricultural drainage water (ADW) for irrigation in hydroponic system in comparison with fresh water irrigation.

\section{MATERIALS AND METHODS}

Hydroponic NFT system was constructed during 2014 at the greenhouse of Soil and Water Research Department, Nuclear Research Center, Atomic Energy Authority, Inshas, Egypt. Experimental site is located at $30^{\circ} 24^{\prime} \mathrm{N}$ latitude, $31^{\circ} 35^{`} \mathrm{E}$ longitude while the altitude is $20 \mathrm{~m}$ above the sea level.

\section{The Hydroponic System}

Lettuce (Lactuca sativa L.) seeds were sown on $1^{\text {st }}$ Sept., 2014 in Rockwool and transplanted 3 week later into rockwool blocks. On $21^{\text {st }}$ Sept., 2014, at the four- to five-leaf stage, transplants were placed in net cubes and inserted in the NFT hydroponic system. The NFT system was made of plastic PVC Pipes (3 m long $\times 4$ inch diameter) set on a flat surface with a $0.1 \%$ slope. 
Each experimental bloc had twelve plants. Each effluent was complemented with appropriate nutrient solution. Blocs with three treatments and four repetitions of each treatment were applied. After seeding, lettuces were transferred to the experimental units. The irrigation of plants was programmed with a timer to9 put on the pumps 4 times every day for 5 minutes per time. Nutrient solution was delivered at $2 \mathrm{~L}$. $\mathrm{Min}^{-1}$, monitored and adjusted daily for $\mathrm{pH}$ and electrical conductivity (EC). In the NFT system, solution was recycled not replaced but adjusted based on $\mathrm{pH}$ and EC measurements.

\section{Plant Material}

Plant seeds were provided by Agricultural Research Centre, Dokki, Cairo, Egypt. Lettuce (Lactuca sativa L.) seeds were subjected to a germination test to check for their viability before being used; where the results indicated 97\% germination percentage.

\section{Treatment of Seeds and Planting}

Seeds of lettuce were cleaned from debris and other foreign materials, and then the cleaned seeds were surface sterilized by soaking for 30 minutes in a $20 \%$ sodium hypochlorite solution (Clorox bleach) to prevent the formation of mould. Planting tubes and the growing net cubes also were cleaned and disinfected. The seeds were washed well from residues of bleach and re-soaked in tap water overnight (about 12 hours) before sowing. Seeds were sown in the polystyrene trays lined with black plastic sheets and have holes at the bottom to allow drainage of excess water from irrigation.

\section{Irrigation Treatments}

Tubes were irrigated by programming a timer to put on the pumps four times every day for five minutes with three water treatments: three concentrations of agricultural drainage water (ADW) were used, i.e. T1: (100\% agricultural drainage water),T2:( $50 \%$ agricultural drainage water $+50 \%$ fresh water), and T3: (100\% fresh water). The agricultural drainage water (ADW) was harvested from the outlet of drain system of minayer region with a capacity of $2,500 \mathrm{~m}^{3} /$ day. Adequate nutrient solution was added in each treatment with rates of $12.5 \%, 50 \%$, and $100 \%$ from standard nutrient solution for T1, T2, and T3, respectively to enhance plant growth and its contents of the nutritional elements.

\section{Lettuce Yield}

At the end of experiment (50 days after seeding), the produced fresh lettuce was ready for harvest (Plate 1), and green plants with their root mats in the tubes were harvested and the following data were recorded: total fresh and dry lettuce yields, seedling height, and leaves number.

\section{Water Use Efficiency}

Planting tubes were irrigated four times every day for five minutes for each water treatments to provide enough water that keeps seedlings moist. Daily amounts of water used in irrigation were recorded to compute the total amounts used in irrigation throughout the experiment duration. Drained water was recycled in the plastic tanks which were placed under each planting tube. Water consumption $\left(\mathrm{m}^{3} / \mathrm{m}^{2}\right)$ was computed as the following:

Water consumption $\left(\mathrm{m}^{3} / \mathrm{m}^{2}\right)=$ total irrigation water in tank at the beginning of the experiment -total irrigation water in tank at the end of the experiment.

Water use was computed according to:

Water use $=\mathrm{m}^{3}$ water used/ $\mathrm{kg}$ fresh lettuce produced.

Water use efficiency (WUE) was computed according to:

WUE $=\mathrm{kg}$ fresh lettuce produced $/ \mathrm{m}^{3}$ water used.

\section{Chemical Analyses}

\section{Mineral nutrient analysis}

Representative fresh green lettuce samples $(150 \mathrm{~g})$ from each treatment were taken in four replicates at harvest, oven-dried at $70^{\circ} \mathrm{C}$ for 48 hours, ground to pass through a $0.5 \mathrm{~mm}$ sieve, prepared for wet digestion using $\mathrm{H}_{2} \mathrm{SO}_{4}$ and $\mathrm{H}_{2} \mathrm{O}_{2}$ and then subjected to chemical analyses. The nitrogen content was determined using Kjeldahl's method. Samples were prepared for determination of mineral nutrients using dry ashing method (Schouwenberg and Walinge, 1973). Phosphorus was determined using spectrophotometer (Watanabe and Olsen, 1965); potassium and sodium by flame photometer (Ryan et al., 2001), Ca, Mg, Mn, Zn and B by Atomic Absorption Spectrometer (Buck type 210). Some nutritional elements (N, P, K, Ca, $\mathrm{Mg}, \mathrm{Zn}, \mathrm{Na}$, and $\mathrm{B}$ ) in various irrigation waters were also analyzed. 


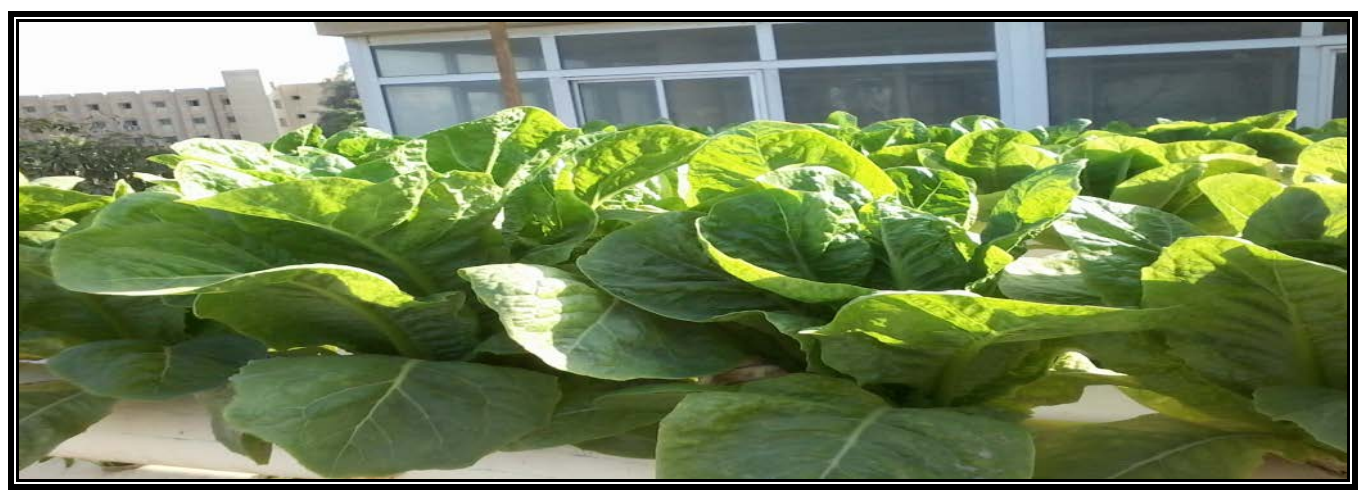

Plate 1. Lettuce plant view at harvest time

\section{Heavy metals analysis}

Dried and ground plant samples as well as various irrigation waters were analyzed for heavy metals $\mathrm{Cd}, \mathrm{Ni}, \mathrm{Cr}$, and $\mathrm{Pb}$.

\section{RESULTS AND DISCUSSION}

\section{Irrigation Water Quality}

Chemical and biological characteristics of irrigation water used for the various treatments are listed in Table 1. The salinity of irrigation water was $0.89 \mathrm{dS} / \mathrm{m}$ (fresh water) and 2.63 $\mathrm{dS} / \mathrm{m}$ (ADW). The $\mathrm{pH}$ values were 7.42 for the fresh water and 7.95 for the ADW.

Concentrations of $\mathrm{N}, \mathrm{K}, \mathrm{Na}, \mathrm{Cl}$ and $\mathrm{Zn}$ in ADW were higher as compared to fresh water (Table 1). However, similar amounts of $P$, $\mathrm{Mg}$, and $\mathrm{B}$ were recorded in both $\mathrm{ADW}$ and fresh water. The concentrations of these elements are considered lower than those recommended for nutrient solutions in crop production (e.g., vegetables) under hydroponic systems according to Benton (2005).

To know the potential risk of heavy metals in irrigation water to plants and hence human beings, it is necessary to evaluate their concentrations in ADW. The heavy metal concentrations of ADW and freshwater used in this study are presented in Table 2. Although the chromium, cadmium, nickel, and lead contents in ADW are much higher than those in fresh water, the levels of these elements in ADW are lower than the acceptable levels set for irrigation water for crop production according to FAO guidelines (FAO, 1992).

\section{Lettuce Yield}

Lettuce yields (on fresh green and dry weight basis), plant height and leaves number at harvest are presented in Table 3. Higher yields of fresh and dry matter were recorded in plants irrigated with T2 than for others. Fresh yield was 2.330, 10.587 , and $7.090 \mathrm{~kg} / \mathrm{m}^{2}$ under irrigation with $\mathrm{T} 1$, T2, and T3, respectively. Consequently, performance of different irrigation water treatments could rank as following: T2>T3> T1. Similar trend was observed with dry matter yield. On line with these results, Gonnella et al. (2003) found that fresh leaf yield of lettuce was on average near to $6 \mathrm{~kg} / \mathrm{m}^{2}$ and leaf dry matter content was on average $5 \mathrm{~g} / 100 \mathrm{~g}$ of fresh weight. In addition, Keller et al. (2005) observed healthy lettuce plants irrigated with secondary effluent diluted 50\% where it achieved high production. Leafy plant production has been reported to highly correlate to $\mathrm{N}$ content of irrigation water (Azevedo et al., 2006). These results confirmed the results we have since the analysis of mixed water or ADW solely (Table 1) used in this study indicated that ADW contains higher $\mathrm{N}$ than fresh water.

Plant dry matter was reduced with increasing water salinity and this is consistent with $\mathrm{Al}-$ Maskri, et al. (2010) but this is inconsistent with the results of Ünlükara et al. (2008) who found that plant dry matter content increased with increasing salinity.

Regarding to plant height, lettuce height recorded 48.40, 52.55, and $47.75 \mathrm{~cm}$ under irrigation with $\mathrm{T} 1, \mathrm{~T} 2$, and $\mathrm{T} 3$, respectively. 
Table 1. The characteristics of fresh water and ADW used for irrigation

\begin{tabular}{lcc}
\hline Parameter & Fresh water & ADW \\
\hline EC dS/m & 0.89 & 2.63 \\
pH & 7.42 & 7.95 \\
DO (mg/l) & - & 2.8 \\
BOD5 (mg/l) & - & 40 \\
COD (mg/l) & - & 38 \\
NO3-N (mg/l) & 14 & 23 \\
Cl (mg/l) & 17 & 129 \\
PO4-P (mg/l) & 4.96 & 6.58 \\
Ca (mg/l) & 48.12 & 59.32 \\
Mg (mg/l) & 15.9 & 17.3 \\
K (mg/l) & 98 & 118 \\
Na (mg/l) & 78.4 & 389 \\
Zn (mg/l) & 0.016 & 0.15 \\
B (mg/l) & 0.038 & 0.050 \\
\hline
\end{tabular}

Table 2. Toxic elements content $\left(\mathrm{mgl}^{-1}\right)$ in water used for irrigation and the maximum concentrations of heavy metals in ADW allowed to be used for irrigation according to FAO (1992)

\begin{tabular}{lccc}
\hline Metal & ADW & Fresh water & $\begin{array}{c}\text { Maximum } \\
\text { concentrations }\end{array}$ \\
\hline Chromium (Cr) & 0.0070 & 0.0018 & 0.10 \\
Cadmium (Cd) & 0.0023 & 0.0004 & 0.01 \\
Nickel (Ni) & 0.0082 & 0.0004 & 0.20 \\
Lead (Pb) & 0.167 & 0.0029 & 5.00 \\
\hline
\end{tabular}

Table 3. Lettuce (fresh and dry) yield, plant height, and leaf number produced under (NFT) hydroponic conditions and irrigated with different concentrations of agricultural drainage water (ADW)

\begin{tabular}{lcccc}
\hline Water treatments & Fresh yield $\mathbf{k g} \backslash \mathbf{m}^{2}$ & Dry yield $\mathbf{~ k g} \backslash \mathbf{m}^{2}$ & plant height, $\mathbf{c m}$ & leaf number \\
\hline T1 & 2.330 & 0.117 & 48.40 & 27 \\
T2 & 10.587 & 0.628 & 52.55 & 29 \\
T3 & 7.090 & 0.351 & 49.75 & 32 \\
\hline
\end{tabular}


Like those of plant dry matter yield, the talles plants were obtained with T2. It could be explained that salinity level provides more nutrients availability when compared with other water treatments. In this respect, Al-Maskri et al. (2010) reported that plants with control treatment produced highest root and shoot length than plants treated with 50 and $100 \mathrm{mM}$ salt, respectively.

Leaf number doesn't vary significantly as affected by different water treatments. In harmony with that results, Andriolo et al. (2005) revealed that number of lettuce leaves was not affected by salinity treatments but this is in contrast to the findings of Ünlükara et al. (2008) who found that number of leaves was reduced significantly with increasing salinity levels.

\section{Water Use Efficiency}

As shown in Table 4, the highest value of (WUE) was obtained with T2 while the lowest WUE value recorded with T1. Irrigation with T2 was found to be more efficient in producing lettuce plant than irrigation with other water treatments. When used only $1 \mathrm{~m}^{3}$ water to produce $39.21 \mathrm{~kg}$ of hydroponic lettuce in comparison to 8,96 , and $24.45 \mathrm{~kg}$ of produced lettuce in T1, T2, and T3, respectively.

Hydroponic system was found to enhance the efficiency of water use (WUE). In the same direction, Bradley and Marulanda (2000) reported that hydroponic vegetables production technique requires only about $10-20 \%$ of the water required to produce the same amount of crop in soil culture. While Al-Karaki (2010) mentioned that, only $3-5 \%$ of water is needed to produce the same amount of plants in comparison to those produced under field conditions. Producing lettuce under hydroponic conditions is a highly efficient process in term of water saving when compared to field production. Gonnella et al. (2003) found that water consumption was near to $80 \mathrm{~L} / \mathrm{m}^{2}$ regardless of plant density, while WUE resulted on average $3.5 \mathrm{~g}$ of leaf dry matter produced per liter of water consumed.

This is a tremendous improvement in WUE and indicated that hydroponic system could play a significant role in improving water use efficiency in Egypt and other countries in the region with shortage in irrigation water.

\section{Lettuce Quality}

\section{Mineral nutrient content in lettuce}

Minerals have a major nutritional significance for human beings and feed deficiencies in elements, such as $\mathrm{N}, \mathrm{P}, \mathrm{K}, \mathrm{Ca}, \mathrm{Cu}, \mathrm{Fe}, \mathrm{Zn}$ and Mn can lead to a variety of health problems (Liu et al., 2007). Concentration of nutrient elements analyzed in dry lettuce is presented in Table 5. There were obvious differences in concentrations of the analyzed elements $(\mathrm{N}, \mathrm{P}$, $\mathrm{K}, \mathrm{Ca}, \mathrm{Cu}, \mathrm{Fe}, \mathrm{Zn}$ and $\mathrm{Mn}$ ) between plants irrigated with ADW and those irrigated with fresh water or mixed one. The short growing period of lettuce under hydroponic dependency on its own reserved compounds for the early growing stages may be attributed to the high variations of mineral nutrients in the produced lettuce irrigated with ADW and fresh water. The nutrient requirements of the seedlings after germination are quite low and partially satisfied from the reserved compounds in the seeds (Bewley, 1997).

The high concentrations of macro nutrients $\mathrm{N}, \mathrm{P}, \mathrm{K}$ and $\mathrm{Ca}$ in dry matter of lettuce irrigated with T3 might be due to their high nutrient concentrations. This might indicate that the nutrient solution concentrations affected the nutrient uptake by lettuce plant. Samarakoon et al. (2006) showed that, increasing nutrient concentration above EC level $2 \mathrm{dS} / \mathrm{m}$, increased nutrients $(\mathrm{N}, \mathrm{P}, \mathrm{K}, \mathrm{Ca})$ uptake by lettuce plant.

On the other hand, all micro nutrient except for $\mathrm{Cu}$, were high in plants irrigated with $\mathrm{T} 2$. This may be attributed to high dry weight value induced by T2. Generally, the contents of essential minerals were available in the produced lettuce around their usual level, thus, ADW can be used for irrigation when mixed with fresh water in ratio of (50\%:50\%) (T2) under hydroponic conditions without any adverse effects.

\section{Heavy metal content in lettuce plant}

Crops irrigated with ADW usually contain elevated levels of heavy metals (specifically Cd, $\mathrm{Ni}, \mathrm{Cr}$ and $\mathrm{Pb}$ ) which might accumulate in plants and cause toxic effects on human being (Adriano, 2001). In this study, heavy metals $(\mathrm{Cd}, \mathrm{Ni}, \mathrm{Cr}$ and $\mathrm{Pb})$ concentrations in lettuce were higher in plants irrigated with $\mathrm{T} 2$ than other water treatments (Table 6). This may be due to dry matter accumulation effect. These are below the limits set by WHO and FAO for leafy vegetables and fresh herb (WHO/FAO, 2007). 
Table 4. Total water applied for lettuce and water use efficiency

\begin{tabular}{lcccc}
\hline Water treatments & $\begin{array}{c}\text { Water } \\
\text { consumption } \\
\mathbf{~ m}^{\mathbf{3}} / \mathbf{m}^{\mathbf{2}}\end{array}$ & $\begin{array}{c}\text { Fresh } \\
\text { matter } \\
\mathbf{K g} / \mathbf{m}^{2}\end{array}$ & $\begin{array}{c}\text { Water use } \\
\mathbf{m}^{\mathbf{3}} \mathbf{/ k g} \text { fresh } \\
\text { matter }\end{array}$ & $\begin{array}{c}\text { Water use } \\
\text { efficiency } \mathbf{~ k g} \\
\text { fresh matter/m }\end{array}$ \\
\hline T1 & 0.26 & 2.330 & 0.112 & 8,96 \\
T2 & 0.27 & 10.587 & 0.026 & 39.21 \\
T3 & 0.29 & 7.090 & 0.041 & 24.45 \\
\hline
\end{tabular}

Table 5. The uptake of mineral nutrients by lettuce plant produced under hydroponic conditions and irrigated with different water treatments (dry matter basis)

\begin{tabular}{lcccccccc}
\hline Water treatment & $\mathbf{N}$ & $\mathbf{P}$ & $\mathbf{K}$ & $\mathbf{C a}$ & $\mathbf{C u}$ & $\mathbf{F e}$ & $\mathbf{Z n}$ & $\mathbf{M n}$ \\
\cline { 2 - 9 } & & & \multicolumn{7}{c}{ mg plant $^{-\mathbf{1}}$} \\
\hline T1 & 94.25 & 11.25 & 144.64 & 30.56 & 0.27 & 24.99 & 1.457 & 1.278 \\
T2 & 281.42 & 31.91 & 507.99 & 80.77 & 0.87 & 56.223 & 3.338 & 2.097 \\
T3 & 479.07 & 34.53 & 636.45 & 172.58 & 1.11 & 37.42 & 2.746 & 1.378 \\
\hline
\end{tabular}

Table 6. The concentration of heavy metals $\left(\mathrm{mg} \mathrm{plant}^{-1}\right)$ in lettuce plant produced under hydroponic conditions and irrigated with different water treatments

\begin{tabular}{lcccc}
\hline Water Treatment & Cd & Ni & Cr & Pb \\
\cline { 2 - 5 } & \multicolumn{5}{c}{ mg plant $^{-1}$} \\
\hline T1 & 0.14908 & 0.572 & 0.806 & 0.12399 \\
T2 & 0.16615 & 1.212 & 2.136 & 0.14821 \\
T3 & 0.09189 & 1.114 & 1.407 & 0.10373 \\
Safe limits in plants & & & & \\
(vegetative parts)(mg/l) & $0.2^{\dagger}$ & $1.5^{\dagger}$ & $20^{\dagger}$ & $5.0^{\dagger}$ \\
\hline
\end{tabular}

† according to WHO/FAO (2007)

\section{Conclusions}

Nutrient Film Technique (NFT) Hydroponic system is a potential technique for lettuce production with less water consumption where water is the main limiting factor for agricultural production. Agricultural drainage water (ADW) is a feasible source for irrigation of hydroponically produced lettuce. The current study shows the superiority of (T2) ADW mixed with fresh water in ratio 0.5/0.5 irrigated lettuce over that irrigated with other water treatments in several aspects related to production and quality of the produced lettuce crop. This indicated that ADW is a good source of nutrients needed for plant growth to promote optimum yields when mixed with fresh water in ratio of $0.5 / 0.5$. The accumulation of heavy metals in the lettuce plants irrigated with ADW was apparent, yet below FAO accepted limits. The use of ADW in hydroponic systems may reduce the risk of heavy metal accumulation in the soil with prolonged use. It is also considered an environmentally sound waste water disposal practice compared to direct disposal into surface or underground water bodies. 


\section{REFERENCES}

Abdel-Lateef, E.M., J.E. Hall, M.A.A. Farrag and A.A. Farrag (2011). Agro- economic studies on wastewater reuse in developing marginal areas in west Delta, Egypt. Int. J. Water Res. and Arid Environ., 1 (2): 110-115

Adriano, D.C. (2001). Trace elements in terrestrial environments: Biogeochemistry, bioavailability and risks of metals. Springer-Verlag, New York.

Al-Karaki, G.N. (2010). Hydroponic green fodder: alternative method for saving water in dry areas. Proceedings of the Second Agricultural Meeting on Sustainable Improvement of Agricultural and Animal Production and Saving Water Use. Sultanate of Oman.

Al-Maskri, A., L. Al-Kharusi and H. Al-Miqbali (2010). Effects of salinity stress on growth of lettuce (Lactuca sativa L.) under closedrecycle nutrient film technique. Int. J. Agric. Biol., 12: 377-380

Andriolo, J.L., G.L. Da Luz, M.H. Witter, R.S. Godoi, G.T. Barros and O.C. Bortolotto (2005). Growth and yield of lettuce plants under salinity. Hort. Brazil., 23: 931-934

Azevedo, M.R.Q.A., A. Kónig, N.E. Beltro, B.S.O. de Ceballos, C.A.V. de Azevedo and T.L. Tavares (2006). Effects of the irrigation with treated wastewater on fodder corn production. Paper number 062094. ASAE Annual Meeting, Portland, Oregon, USA.

Benton, J. (2005). Hydroponics; A Practical Guide for the Soilless Grower. $2^{\text {nd }}$ Ed. CRC Press, USA.

Bewley, J. D. (1997). Seed germination and dormancy. The Plant Cell., 9:1055-1066.

Bradley, P. and C. Marulanda (2000). Simplified hydroponics to reduce global Hunger. Acta. Hort., 554: 289-295.

FAO (Food and Agriculture Organization of the United Nations). (1992). Wastewater quality guidelines for agricultural use. In: Pescod, M.B. (Ed) Wastewater treatment, and use in agriculture-FAO irrigation and drainage paper 47. Rome, Italy, 25-35.
Gonnella M., F. Serio G. Conversa and P. Santamaria (2003). Yield and quality of lettuce grown in floating system using different sowing density and plant spatial arrangements. Proc. $6^{\text {th }}$ IS on Protected Cult. Eds: G. La Malfa et al. Acta Hort 614, ISHS Hunger. Acta Hort., 554 : 289-6

Keller, R., K. Perim, S. Semionato, E. Zandonade, S. Cassini, and R.F. Gonçalves (2005). Hydroponic cultivation of lettuce (Lactuca sativa L.) using effluents from primary, secondary and tertiary + UV treatments .Water Science and Technology: Water Supply, 5 (1): 95-100.

Liu, K., K.L. Peterson and V. Raboy (2007). Comparison of the phosphorus and mineral concentrations in bran and abraded kernel fractions of a normal barley (Hordeum vulgare) cultivar versus four low phytic acid isolines. J. Agric. Food Chem., 55 : 44534460.

Rababah, A. and A. Al-Shuha (2009). Hydroponics reducing effluents heavy metals discharge. Water Sci. Tech. 59:175-183.

Rababah, A.A. and N.J. Ashbolt (2000). Innovative production treatment hydroponic farm for primary municipal sewage utilization. Water Res., 34 (3): 825-834.

Ryan, J., G. Estefan and A. Rashid (2001). Soil and Plant Analysis Laboratory Manual. $2^{\text {nd }}$ Ed. International Center for Agricultural Research in the Dry Areas ICARDA, Aleppo, Syria.

Samarakoon, U.C., P.A. Weerasinghe and W.A.P. Weerakkody (2006). Effect of electrecal conductivity[EC] of the nutrient solution on nutrient uptake, growth and yield of leaf lettuce (Lactuca sativa L.) in stationary culture. Tropical Agric. Res., 18.

Schouwenberg, V. and J.C. Walinge (1973). Methods of analysis for plant material. Agric. Univ., Wageningen, the Netherlands.

Sezen, S.M., G. Celikel, A. Yazar, S. Tekin and B. Kapur (2010). Effect of irrigation management on yield and quality of tomatoes grown in different soilless media in a glasshouse. Sci. Res. Essays, 5 (1): 41-48. 
Snow, A.M. and A.E. Ghaly (2008). Use of Barley for the Purification of Aquaculture Wastewater in a Hydroponics System. Ame. J. Environ. Sci., 4 (2): 89-102.

Ünlükara, A., B. Cemek, S. Karaman and S. Erşahin (2008). Response of lettuce (Lactuca sativa var. crispa) to salinity of irrigation water. New Zealand J. Crop Hort. Sci., 36: 265-273

Vaillant, N., F. Monnet, H. Sallanon, A. Coudret and A. Hitmi (2004). Use of commercial plant species in a hydroponic system to treat domestic wastewaters. J. Environ. Qual., 33 (2): 695-702.
Watanabe, F.S. and S. Olsen (1965). Test of an ascorbic acid method for determining phosphorus in water and $\mathrm{NaHCO}_{3}$ extract for soil. Soil Sci., 21:677-678.

WHO/FAO (2007). Joint FAO/WHO Food Standard Programme Codex Alimentarius Commission $13^{\text {th }}$ Session. Report of the Thirty Eight Session of the Codex Committee on Food Hygiene. Houston, United States of America.

Yang, Z., S. Zheng, J. Chena and M. Suna (2008). Purification of nitrate-rich agricultural runoff by a hydroponic system. Biores. Techn.

\section{استخدام مياه الصرف الزراعى فى إنتاج الخس فى نظام الغثاء الرقيق من الزراعة المائية \\ عبدالقادر مصطقى محمد' - عبدالتواب متولى إبراهيم زيدان' - مجدى أحمد رزق'

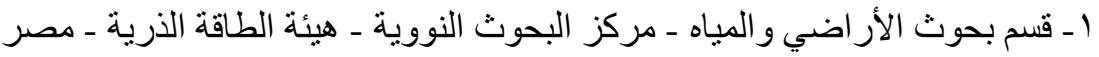 \\ r ـ قسم الهندسة الزراعية ـ كلية الزراعة ـ جامعة الزقازيق ـ مصر}

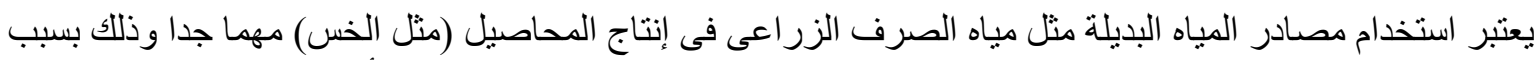

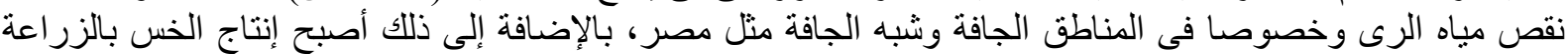

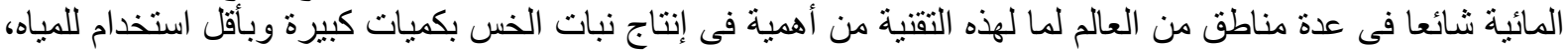

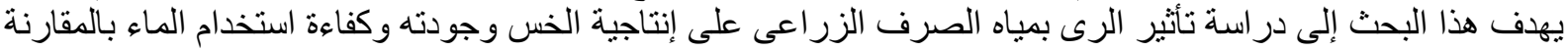

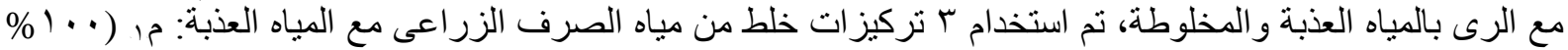

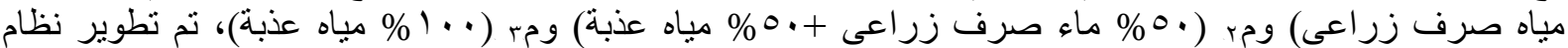

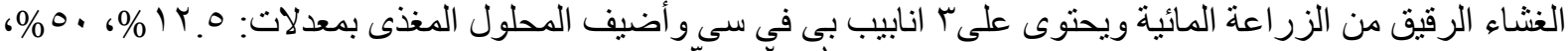

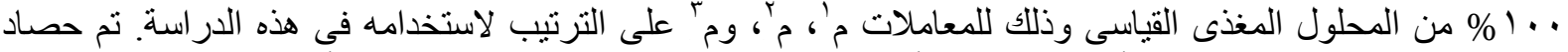

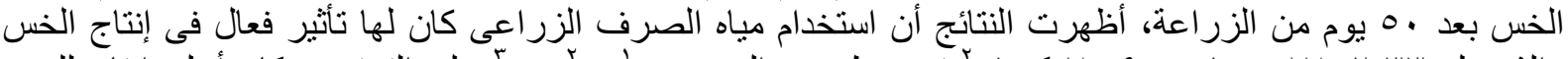

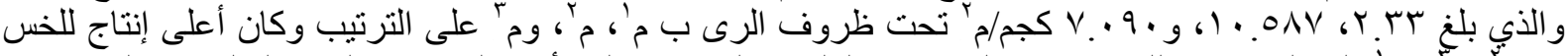

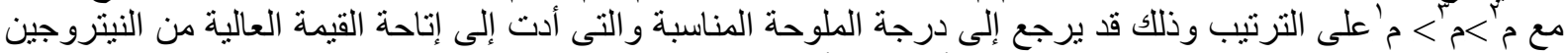

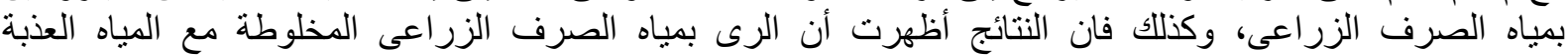

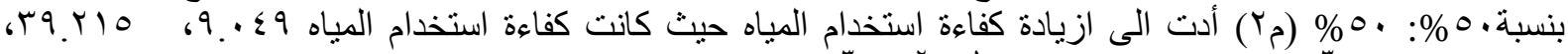

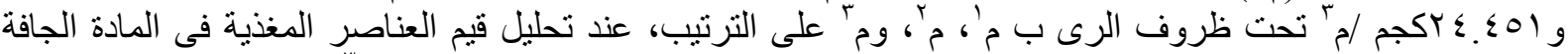

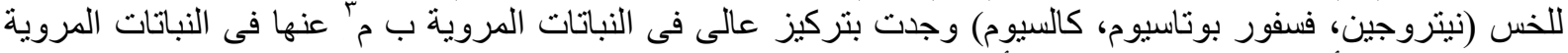

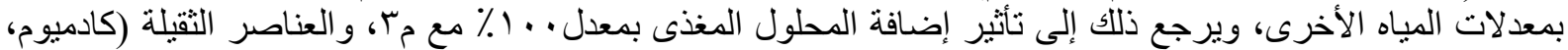

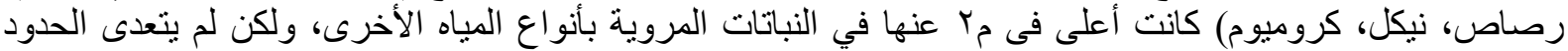

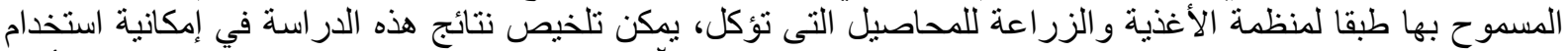

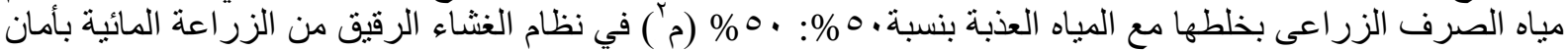

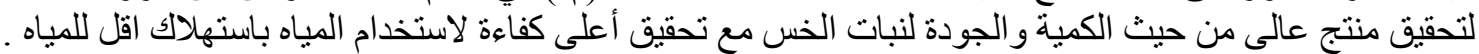

أستاذ ميكروبيولوجيا الأر اضي ـ مركز البحوث النووية ـ هيئة الطاقة الذرية.

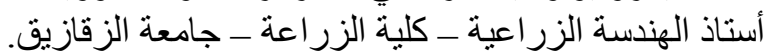

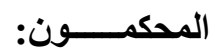

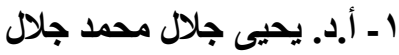

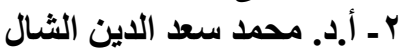

